УДК 377.354:001.4

DOI:

Галина Носуліч, аспірант

Національного університету “Львівська політехніка"

\title{
КОРПОРАТИВНА ОСВІТА - ПІДХОДИ ДО ВИЗНАЧЕННЯ ТЕРМІНУ
}

У статті проаналізовано окремі аспекти поняттєво-категорійного апарату корпоративної освіти, яка знаходиться на перетині педагогічної та управлінської сфер. Розглянуто деякі підходи до визначення досліджуваного поняття. Показано взаємозв 'язок корпоративної освіти із такими поняттями, як освіта, професійна освіта, розвиток персоналу тощо. Показано співвідношення між поняттями "корпоративна освіта" та “розвиток персоналу”. Дослідження також сфокусоване на розрізненні взаємозалежних термінів у даній сфері, таких як корпоративна освіта, корпоративне навчання, корпоративна підготовка.

Ключові слова: корпоративна освіта; корпорачія; освіта; корпоративне навчання; розвиток персоналу. Jim. 15.

Halyna Nosulich, Postgraduate Student National University "Lviv Polytechnic"

\section{THE CORPORATE EDUCATION - APPROACHES TO DEFINING THE TERM}

The article considers some conceptual and categorial aspects of corporate education which allow defining the very concept "corporate education". In order to avoid terminological misunderstanding, defining the foundational terms of any subject area is obligatory. An analysis of scientific findings and meticulous selection of terms enable setting conceptual connections between items, eliminating their misunderstanding, selecting adequate Ukrainian correspondents to the terms already established in foreign languages.

An analysis of the latest researches and publications in the sphere indicates that the problem of defining corporate education in the most comprehensive way has become a center of attention for theoretical works of foreign and home specialists. The investigation of corporate education is inevitably connected with the analysis of researches in the fields of adults' learning, lifelong learning, human resource management and development etc. This is caused by the position of corporate education on the intersection of pedagogy and organizational management.

The research is also focused around differentiating various subject area-related terms. It is emphasized that corporate education, corporate training, corporate learning are different concepts, though often used interchangeably in the same context in the Anglophone scientific literature. The same approach relates to the corporate education vs. human resource development relation.

The special attention is paid to knowledge-based economy which encompasses corporate education, thus, increasing its importance in the modern world. Singling out the corporate competences has allowed deeper understanding of the relevance of appropriate corporate education since this leads to understanding what should be a focus of an organization for achieving certain strategic goals. The article leaves the question of a single consolidated definition of corporate education open due to its broad and multifaceted nature.

Keywords: corporate education; corporation; an education; corporate learning; the human resource development.

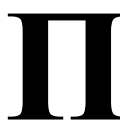

остановка проблеми. Навчання персоналу все більше набуває характеру необхідності для підтримання конкурентоспроможності підприємств на внугрішніх і світових ринках. Щоб іти в ногу 3 часом, компаніям потрібно постійно навчати своїх працівників новим навичкам, необхідним для досягнення успіху. Разом з цим можливості для росту і розвитку стають щораз важливішим критерієм в кар'єрному виборі найяскравіших талантів. Тому інвестиції в таких працівників через навчальні програми - це інвестиції в далекоглядне майбутнє для самої компанії. Навчання і розвиток персоналу стали центральними сферами, які кожна компанія на сучасному ринку повинна вдосконалювати.

У багатьох випадках навчання і розвиток в організаціях по замовчуванню засноване на індивідуальному самостійному розвитку спеціалістів. Проте все більше керівників починають дивитися на навчання своїх працівників 3 іншої точки зору. Зокрема, багато коштів інвестується в корпоративну освіту самими організаціями та проводиться пошук ефективних шляхів для покращення рентабельності таких інвестицій. Багато організацій усвідомлюють стратегічну роль корпоративної освіти та її вплив на саму організацію, а не лише на окремих працівників.

Щоби мати змогу визначити будь-яке поняття, необхідно проаналізувати поняттєво-котегорійний апарат дослідження, для систематизації якого охарактеризуємо зв'язки між основними поняттями. Як зазначає Лісова, “понятійно- 
термінологічне оформлення... характеризує результати, рівень теоретичного осмислення певної сфери об'єктивної дійсності та сприяє розкриттю їі сутності, предмета, провідної системотвірної ідеї’ $[8,14]$.

Для уникнення термінологічної плутанини надзвичайно важливо дати визначення базової термінології дослідження. Це стає можливим лише на основі аналізу наукових джерел та ретельного добору термінів, які дають змогу встановити смислові зв'язки між одиницями, запобігти їхньому неоднозначному тлумаченню, підібрати адекватні відповідники іншомовних понять в українській мові. Литовченко переконана, що “логічне структурування понять категоріального апарату, ... угочнення та доповнення їхнього змісту дають змогу глибше осмислити й повніше проаналізувати досліджуване явище" [7, 44].

Аналіз останніх досліджень і публікацій свідчить про те, що проблема окреслення поняттєво-категорійного апарату корпоративної освіти стала предметом дослідження досить великої кількості науковців у педагогічній, економічній та управлінській сферах. Різні підходи до окреслення поняттєво-категорійного апарату будь-якого педагогічного дослідження обгрунтовано в працях Блума (Bloom), Содерсквіта (Soderquist), Яковлевої. Сутність та особливості корпоративної освіти у своїх працях розкривають такі зарубіжні та вітчизняні науковці, як Віллер (Wheeler), Райян, (Ryan), Плессіс (Plessis), Майстер (Meister), Розенбаум (Rosenbaum), Гольшенкова, Маншукова, Литовченко, Харчишин, Красношапка, Грибник тощо.

Дослідження корпоративної освіти невідривно пов'язане 3 аналізом досліджень навчання дорослих (Кід (Kidd), Мерріам (Merriam), Ноуелс (Knowles), Зязюн, Гончаренко) та неперервної професійної освіти (Дейв (Dave), Базаров, Мукан, Андрющенко, Зязюн, Синенко, Лісова тощо), а також управління та розвитку персоналу (Гарбісон (Harbison), Вілсон (Wilson), Армстронг (Armstrong), Маншукова, Грибник, Копець).

Мета статті - визначити поняття “корпоративна освіта" через аналіз поняттєвокатегорійний апарату досліджуваної проблеми на основі існуючих досліджень та підходів.

Виклад основного матеріалу. Щоб глибше зрозуміти суть центрального поняття в нашому дослідженні - "корпоративна освіта" - варто найперше підійти до цього питання з лінгвістичної точки зору. Смислова структура поняття “корпоративна освіта" складається із двох компонентів: “корпоративна”, що є похідним від “корпорація”, та “освіта”.
Правильне визначення поняття “корпорація" дозволить нам уникнути термінологічних неточностей. Дане поняття належить до економічної сфери і тлумачиться як “сукупність осіб, об’єднана для досягнення будь-якої мети, здійснення спільної діяльності та утворення самостійного суб' єкта права” та “природноісторичне об’єднання представників однієї професії зі своїм стилем життя, етикою, законами та ін.” [4, 153]. В українському законодавстві корпорація - це договірне об'єднання, створене на основі поєднання виробничих, наукових і комерційних інтересів підприємств, що об'єдналися, 3 делегуванням ними окремих повноважень централізованого регулювання діяльності кожного 3 учасників органам управління корпорації [2]. Стівен Боттомлі (Stephen Bottomley) наголошує на тому, що важливість корпорацій в сучасному суспільстві не обмежується сектором приватного бізнесу. Корпоративні форми організацій зараз дуже поширені в некомерційній сфері, у тому числі серед громадських, релігійних, спортивних, освітніх, професійних організацій [10,2 -3]. Тобто значення терміна “корпорація" виходить за межі чіткого юридичного визначення і вживається як синонім термінів “організація”, “компанія”, “фірма”, “підприємство”. У контексті нашого дослідження вважаємо за доцільне дотримуватися такого тлумачення цих понять і вживати їх як взаємозамінні терміни, оскільки для нас важливим є дослідження навчальних процесів, а не правові особливості функціонування цих суб'єктів економічної діяльності.

Поняття “освіта" - багатозначне та поліфункціональне. За означенням, прийнятим XX сесією Генеральної конференції ЮНЕСКО, освіта - це процес і результат удосконалення здібностей і поведінки особистості, при якому вона досягає соціальної зрілості та індивідуального зростання [15]. В “Українському педагогічному словнику" Гончаренка освіта трактується як “духовне обличчя людини, яке складається під впливом моральних і духовних цінностей, що є надбанням iii культурного кола, а також процес виховання, самовиховання, впливу, шліфування”. При цьому наголошується на вмінні розпоряджатися своїми знаннями та поєднувати виховання із особистісними якостями [1, 241]. Зязюн наголошує на тому, що освіта - це “не просто задана ззовні програма розвитку людини, а діяльність самої людини з оволодіння соціальним досвідом”, це “невпинне цілеспрямоване засвоєння людиною соціокультурного досвіду 3 використанням усіх ланок існуючої освітньої системи" $[6,13]$. Закон України "Про Освіту" 
визначає освітній процес як “систему науковометодичних і педагогічних заходів, спрямованих на розвиток особистості шляхом формування та застосування іiі компетентностей” і трактує освіту як основу інтелектуального, духовного, фізичного і культурного розвитку особистості з метою всебічного розвитку людини як найвищої цінності суспільства [5].

У законодавстві України чітко окреслений взаємозв'язок освіти дорослих, що є складовою освіти впродовж життя і спрямована на реалізацію права кожної повнолітньої особи на безперервне навчання з урахуванням іiї особистісних потреб, пріоритетів суспільного розвитку та потреб економіки. Безперервний професійний розвиток трактується законодавством як безперервний процес навчання та вдосконалення професійних компетентностей фахівців після здобуття вищої та/або післядипломної освіти, що дає змогу фахівцю підтримувати або покращувати стандарти професійної діяльності і триває впродовж усього періоду його професійної діяльності [5]. Туг ідеться про постійний розвиток людини, важливість забезпечення неперервної освіти стала домінуючою концепцією розвитку освіти. Очевидно, що корпоративну освіту не можна розглядати поза контекстом неперервного навчання в системі освіти дорослих.

Неперервна освіта - визначається як процес, що відбувається протягом життя і передбачає розвиток творчого потенціалу особистості та всебічне збагачення іiї духовного світу, забезпечує цілеспрямовану систематичну пізнавальну діяльність людини щодо засвоєння і вдосконалення знань, умінь і навичок $[3,10]$. В контексті нашого дослідження важливим $€$ бачення Кідда, щодо неперервної освіти як механізму, що впливає на суспільство, інструмент зміни способу життя людини, підхід до економічного та соціального процвітання, відповідь на динамічні соціальні зміни $[12,34]$.

Освіта дорослих по своїй суті обширне і багатоаспектне поняття. Ноулз пропонує три значення цього поняття. В своєму найширшому значенні освіта дорослих стосується будь-якого досвіду навчального процесу дорослої людини. 3 технічної точки зору освіта дорослих охоплює організовану діяльність, яку здійснюють різноманітні заклади для досягнення певних навчальних цілей. Третій підхід до тлумачення поняття по своїй суті об'єднує два попередні і виливається в “ідею про рух або галузь соціальної практики" $[13,25]$. Для нашого дослідження особливе значення має визначення поняття “неперервна професійна освіта дорослих”, яку
Литовченко вважає важливим механізмом “досягнення відповідності між вимогами ринку праці (корпорації, фірми) та швидкою адаптацією до нових вимог, кваліфікацій” [7, 52].

Наше дослідження вимагає пояснення термінів “корпоративна підготовка" (corporate training) та “корпоративне навчання” (corporate learning), які вживаються поряд з поняттям “корпоративна освіта" (corporate education) та інколи розуміються як тотожні.

Корпоративну підготовку (“corporate training”) можна розуміти як набуття працівниками знань i навичок, які їм необхідні для якісного виконання своїх обов'язків. Корпоративне навчання спрямоване в першу чергу на розвиток компетентностей працівників. Підготовка спеціалістів в компаніях, як зазначає Н. Машукова, доповнює знання, здобуті в школі чи вищому навчальному закладі, дає можливість пристосовуватися до виробничих потреб організації [9, 78]. Основна функція організації корпоративного навчання - забезпечити працівника знаннями і навиками для виконання спеціальних функцій, необхідних для діяльності компанії. Кремень розглядає освіту як широке поняття, що, крім іншого, охоплює й підготовку, яка “спрямована на досягнення конкретних навчальних завдань, особливо в рамках професійної освіти" [3, 303]. Литовченко переконана, що таке трактування цього терміна пояснюється його історичним походженням, оскільки “його пов’ язують із часами, коли виникло учнівство (apprenticeship) як найдавніша форма професійної освіти в англомовному світі, за якого учень навчався професії, набував необхідних умінь та навичок безпосередньо на робочому місці" (Литовченко. Орпоративна освіта у... с. 62).

Ліндсей Раян (Lindsay Ryan) визначає відмінність корпоративної освіти і корпоративної підготовки через їхній взаємозв'язок із корпоративним знанням (“corporate knowledge") як вихідної точки для навчання і розвитку. Основне завдання корпоративної підготовки підсилення і підтримка навиків і компетенцій спеціалістів. Працівники проходять корпоративні навчальні програми, щоби виконувати новопризначені обов'язки або щоби розвинути якусь компетентність до нового рівня. Таким чином спеціаліст розвиває компанію через власний розвиток $[14,11-13]$.

В свою чергу, корпоративна освіта відіграє ключову роль в створенні проактивного середовища, дослідженні прогресивних ідей, накопиченні нових знань. Корпоративна освіта розширює об'єм знань всередині компанії. 
Зважаючи на зростаючу роль “економіки, в основі якої знання" ("knowledge based economy"), нові знання - неоціненний інтелектуальний капітал компанії, життєво важливе джерело нових можливостей для бізнесу.

По своїй суті корпоративна підготовка грунтується на передачі знань. Корпоративна освіта сфокусована на спроможність організації функціонувати стабільно і успішно. Компанія повинна передбачати, що в майбутньому більшість їі лідерів та ініціатив повинні розвиватися всередені компанії, а не приходити із зовнішніх джерел. Це відбуватиметься, перш за все, через нестачу або конкуренцію між компаніями за працевлаштування відповідно кваліфікованих, навчених і досвідчених кадрів. 3 цього випливає стратегічна роль корпоративної освіти для будьякої організації. Корпоративна освіта має потенціал трансформувати компанію і полегшити розвиток іiї конкурентоздатності в світовому бізнес-середовищі. Вона $є$ не лише засобом для поглиблення знань, формування та розвитку умінь та навичок працівників, а й віддзеркалення глибини культури, потужності та стабільності організації. Отже, корпоративне навчання забезпечує підтримку існуючої операційної ефективності компанії. Корпоративна освіта, в свою чергу, є засобом посилення знань, навиків і компетенцій працівників для поступу вперед.

Енциклопедичний словник “Освіта дорослих” подає таке визначення поняття “корпоративна освіта": “корпоративна освіта (система корпоративного навчання) - це комплекс заходів щодо підвищення кваліфікації та розширення професійних знань і вмінь спеціалістів у рамках однієї організації” $[3,280]$. Потрібно розуміти, що корпоративна освіта відрізняється від професійної освіти, зважаючи на їхню мету і функції. Система професійної освіти спрямована на забезпечення кваліфікованими працівниками ринку праці, коли мета корпоративної освіти - розвиток кадрів певної організації.

Поряд із терміном “корпоративна освіта" в науковій літературі використовується "розвиток персоналу”. розвиток персоналу-ширше поняття, ніж корпоративна освіта, оскільки, окрім навчання працівників, включає в себе й інші аспекти використання кадрового потенціалу через його розвиток, наприклад, планування кар'єрного шляху, організацію і ведення кадрового резерву тощо. Тому не варто вживати ці поняття як тотожні.

Вважаємо доцільним визначити поняття i “економіка, заснована на знаннях" (knowledgebased economy), яка відповідає за створення багатства шляхом накопичення і використання знань. В основі економіки знань лежать створення, розповсюдження і використання знань, що чітко виявляє зв'язок цього поняття із корпоративною освітою.

Знання в наш час вважається найціннішим активом організації. Стрімкий розвиток інформаційної сфери зумовили необхідність в управлінні (менеджменті) знаннями (Knowledge Management), яке частково лежить в площині корпоративної освіти. Управління знаннями визначається науковцями як “процес застосування системного підходу для угримання, структурування, управління та розповсюдження знання в організації для швидшого виконання роботи, використання найкращих практик, скорочення затратних операцій” $[11,3]$. При ефективному управлінні знаннями доцільність і якість корпоративної освіти зростає, оскільки в організації відбувається обмін кращим досвідом і навчання на основі цього.

Ширшим є поняття “управління людськими ресурсами" (human resource management), тобто формування, використання, розвиток трудових, інтелектуальних, творчих, підприємницьких здібностей і моральних якостей працівників задля покращення ефективності і конкурентоспроможності організації в ринковому середовищі. Литовченко вважає, що “концепція управління людськими ресурсами обгрунтовує економічну доцільність капіталовкладень у неперервне професійне навчання персоналу корпорації, створення сприятливих умов для прояву їхніх здібностей і можливостей” [7, 57].

Потрібно розуміти, що поняття “корпоративна освіта" i “розвиток персоналу" не тотожні поняття. На даний час ще не має єдиного розуміння поняття "розвиток людських ресурсів". Зрозумілим є тільки те, що це поняття є ширшим за корпоративну освіту, оскільки включає в себе управління знаннями і охоплює цілунизку процесів, пов'язаних із навчанням: підготовку, навчання й розвиток, навчання на робочомумісці, підвищення кваліфікації, планування кар'єри, навчання протягом життя, розвиток організації, управління знаннями". Зростаюче значення професійного навчання та розвиткуй значне збільшення потреби в ньому призвели до того, що організація професійного навчання стала однією із основних функцій управління персоналом.

Як зазначалося раніше, результатом корпоративного навчання $є$ набуття, формування або підвищення корпоративної компетентності. Процес визначення “корпоративних компентностей”, важливих всередині компанії, дозволяє зрозуміти, на чому організація повинна сфокусуватися, а 
чому слід приділяти менше уваги. Центральну роль у розвитку і підсиленні корпоративних компетентностей відіграє, яке, на думку Литовченко, “повною мірою реалізується в корпоративному університеті, тому корпоративний університет вважають найбільш прогресивною формою корпоративної освіти" [7, 74]. При цьому корпоративні університети можуть мати різні масштаби та носити різні назви, але це питання для окремого дослідження.

Висновок. Проведений аналіз термінологічної бази дав змогу розглядати вихідне поняття нашого дослідження “корпоративна освіта" як явище економіки, заснованої на знаннях; систему, яка $\epsilon$ важливою складовою освіти впродовж життя, зокрема неперервної професійної освіти дорослих; складову бізнесу, націлену на досягнення відповідних цілей; формування, спрямоване на задоволення потреб компанії в управлінні знаннями, розвиткукорпоративних компетентностей; процес і результат набугтя знань, умінь та навичок в межах організації для досягнення стратегічних цілей та підвищення ефективності професійної діяльності. Як бачимо, оскільки поняття “корпоративна освіта" дуже широке i багатоаспектне, питання єдиного підходу до його визначення залишається відкритим.

\section{ЛІТЕРАТУРА}

1. Гончаренко С. У. Український педагогічний словник / С. У. Гончаренко (гол. ред. Головко С.). - К. : Либідь, 1997. - 374 с.

2. Господарський кодекс України // Відомості Верховної Ради України (ВВР). - № 18, № 19-20, № 21-22. - 2003 .

3. Енциклопедія освіти / (Акад. пед. наук України; гол. ред. В. Г. Кремень). - К. : Юрінком Інтер, 2008. - $1040 \mathrm{c}$.

4. Завадський Й. С. Економічний словник / Й.С. Завадський, Т.В. Осовська, О.О. Юшкевич. - К. : Кондор, 2006. - 355 с.

5. Закон України "Про освіту" // Відомості Верховної Ради (ВВР). - № 38-39. - 2017.

6. Зязюн I. А. Неперервна освіта: концептуальні засади і сучасні технології / І.Я. Зязюн // Творча особистість у системі неперервної професійної освіти: міжнар. наук. конф., 16-17 трав. 2000 р. / за ред. С. О. Сисоєвої, О. Г. Романовського. Харків: ХДПУ, 2000. - С. 8-16.

7. Литовченко I. М. Корпоративна освіта у Сполучених Штатах Америки: теорія і практика: монографія / I.М. Литовченко; Національна академія педагогічних наук України, Інститут педагогічної освіти і освіти дорослих. - Київ: Б.А. Сладкевич, 2017. - 399 с.
8. Лісова Н. І. Розвиток психолого-педагогічної компетентності молодих вчителів у системі післядипломної освіти: дис. ... канд. Пед. Наук : 13.00.04 / Н. І. Лісова. - К., 2005. - 210 с.

9. МаншуковаН. Д. Организация внугрифирменного обучения персонала / Н. Д. Машукова. - Ярославль: ГОУДПО ЯрИПК, 2002. - 78 с.

10. Bottomley S. Constitutional Corporation: Rethinking Corporate Governance / S. Bottomley. Aldershot, England; Burlington, VT: Ashgate, 2007. $-183 \mathrm{p}$.

11. Goff T. R., Jones T. P. An Introduction to Knowledge Management / T.R. Goff, T.P. Jones. Routledge, 2011. - 194 p.

12. Kidd J. R. How Adults Learn / J.R. Kidd. Englewood Cliffs, NJ: Cambridge Adult Education, 1978. $-318 \mathrm{p}$.

13. Knowles M. S. The Modern Practice of Adult Education: From Pedagogy to Andragogy/M.S. Knowles. - Chicago: Associated Press Follett Publishing Company, 1980. $-400 \mathrm{p}$.

14. Ryan L. Corporate Education: A Practical Guide to Effective Corporate Learning / L. Ryan. Adelaide : Griffin Press, 2010. - 268 p.

15. UNESCO. Records of the General Conference, Twentieth Session: Resolutions (Paris, 24 October - 25 November, 1978) / the United Nations Educational, Scientific and Cultural Organization. - V. 1. - Paris : Imprimerie des Presses Universitaires de France, 1979. - 205 p.

\section{REFERENCES}

1. Honcharenko, S. U. (1997). Ukrainskyi pedahohichnyi slovnyk [Ukrainian pedagogical dictionary]. Kyiv: Lybid. 374 p. [in Ukrainian].

2. Hospodarskyi kodeks Ukrainy (2003). [Economic Code of Ukraine]. No. 18, No.19-20, No. 2122. [in Ukrainian].

3. Kremen, V. H. (2008). Entsyklopediia osvity [Encyclopedia of education]. Kyiv: Yurinkom Inter. 1040 p. [in Ukrainian].

4. Zavadskyi, Y. S. (2006). Ekonomichnyi slovnyk [Economic dictionary]. Kyiv: Kondor, 355 p. [in Ukrainian].

5. Zakon Ukrainy "Pro osvitu" (2017). [Ukrainian law "On Education"]. No.38-39. [in Ukrainian].

6. Ziaziun, I. A. (2000). Neperervna osvita: kontseptualni zasady i suchasni tekhnolohii [Continuous education: conceptual basics and modern technologies]. Kharkiv: KhDPU, pp. 8-16. [in Ukrainian].

7. Lytovchenko, I. M. (2017). Korporatyvna osvita u Spoluchenykh Shtatakh Ameryky: teoriia i praktyka: monohrafiia [Corporate education in the United States of America: theory and practice: 


\section{ДОПИТАННЯФОРМУВАННЯЦІННІСНОГОСТАВЛЕННЯ ДОСТВОРЕННЯСІМ'̈̈ У СТУДЕНТІВ АГРАРНИХ КОЛЕДЖІВ}

monography]. Kyiv: B.A. Sladkevych, 399 p. [in Ukrainian].

8. Lisova, N. I. (2005). Rozvytok psykholohopedahohichnoi kompetentnosti molodykh vchyteliv u systemi pisliadyplomnoi osvity [Development of psychological and pedagogical competence of young teachers in the system of post-graduate education]. Candidate's thesis. Kyiv, 210 p. [in Ukrainian].

9. Manshukova, N. D. (2002). Orhanyzatsyia vnutryfyrmennoho obuchenyia personala [Organization of employees' learning within a firm]. Yaroslavl: HOUDPO YarYPK, 78 p. [in Russian].

10. Bottomley, S. (2011). Constitutional Corporation: Rethinking Corporate Governance. Aldershot, England; Burlington, VT: Ashgate. 183 p. [in English].

11. Goff ,T. R. \& Jones, T. P. (2011). An
Introduction to Knowledge Management. Routledge. 194 p. [in English].

12. Kidd, J. R. (1978). How Adults Learn. Englewood Cliffs, NJ: Cambridge Adult Education. 318 p. [in English].

13. Knowles, M. S. (1980). The Modern Practice of Adult Education: From Pedagogy to Andragogy. Chicago: Associated Press Follett Publishing Company, 400 p. [in English].

14. Ryan, L. (2010). Corporate Education: A Practical Guide to Effective Corporate Learning. Adelaide: Griffin Press, 268 p. [in English].

15. UNESCO. Records of the General Conference, Twentieth Session: Resolutions (Paris, 24 October - 25 November, 1978) V. 1 (1979). Paris: Imprimerie des Presses Universitaires de France, 205 p. [in English].

Стаття надійшла до редакції 26.04.2018

УДК 377.015.31:378.663-057.87

DOI:

Надія Шелест, здобувач кафедри педагогіки Національного університету біоресурсів і природокористування Украӥни, м. Київ

\section{ДО ПИТАННЯ ФОРМУВАННЯ ЦІННІСНОГО СТАВЛЕННЯ ДО СТВОРЕННЯ СІМ'Ї У СТУДЕНТІВ АГРАРНИХ КОЛЕДЖІВ}

У статті розкрито практичні аспекти реалізації однієї із форм формування иіннісного ставлення до створення сім '̈̈ у студентів аграрних коледжів у позааудиторній діяльності-система кураторських годин “Я-майбутній сім'янин”, основними завданнями яких є: озброєння студентської молоді системою юридичноправових знань, які стосуються становлення, розвитку та процвітання сім'ї на основі любові, поваги та згуртованості; формування моральних якостей, необхідних для спільного життя чоловіка та жінки, батька та матері; актуалізачія потреби у самоусвідомленні й розвитку особистісних якостей, потрібних для майбутнього сімейного життя.

Ключові слова: иіннісне ставлення до створення сім'ї; кураторські години; студенти аграрних коледжів; позааудиторна діяльність; методи формування ціннісного ставлення до створення сім' $\dddot{\text {. }}$

Jim. 6.

Nadiya Shelest, Applicant of the Pedagogy Department National University of Life and Environmental Sciences of Ukraine, Kyiv

\section{TO THE ISSUE OF DEVELOPING A VALUE ATTITUDE TO THE CREATION OF A FAMILY AMONG STUDENTS OF AGRICULTURAL COLLEGES}

The article presents the practical ideas of realizing tools of developing a value attitude to the creation of family among students of agricultural colleges during after class activities. It is a system of mentor's hours "I am a future family member". The main tasks of this system are to provide the students with a bulk of knowledge about laws which relate to the creation, development and prosperity of a family on the basis of love, respect and family cohesion; to form the moral qualities which are necessary for marital life, for the life of a father and mother; getting to know the fundamentals of housekeeping and the distribution of family budget; the actualization of the need of self-awareness and the development of personal qualities necessary for future family life.

In order to choose the best ways of organizing after class activities which will develop a value attitude to the creation of a family among students of agricultural colleges, it is necessary to take into account the fact that after class activities should be selected to meet the students' personal features, needs and interests.

The article gives a brief description of the mentor's hour "My future family". This mentor's hour aimed at modeling of students' future families, its members and relationship. The students participated in different activities, such as "My future family", "Family album", "Ukrainian proverbs about family relationship". The paper describes 